\title{
SIKAP, MOTIVASI DAN KEMAMPUAN PETUGAS DALAM MENINGKATKAN EFEKTIVITAS PEMUNGUTAN PAJAK BUMI DAN BANGUNAN SEKTOR PERDESAAN DAN PERKOTAAN DI KOTA BANJAR
}

\author{
Maman Sulaeman \\ Program Studi Manajemen Industri, Politeknik Triguna Tasikmalaya \\ mansulaeman1274@gmail.com \\ Ismayudin Yulizar \\ Program Studi Manajemen, Universitas Muhammadiyah Tangerang \\ ismayudin.yulizar@umt.ac.id \\ Yanti Nurdiyanti \\ Program Studi Manajemen Pendidikan Islam, STIT NU Al Farabi \\ yanti36.alfarabi@gmail.com
}

\begin{abstract}
ABSTRAK
Permasalahan dalam penelitian ini adalah bagaimana sikap, motivasi dan kemampuan pekerja pengumpul Pajak Bumi dan Bangunan terhadap efektifitas pemungutan pajak atas tanah dan bangunan. Penelitian ini dilakukan menggunakan metode analisis deskriptif dengan teknik survei. Populasi dalam penelitian ini petugas pajak di Banjar. Teknik sampling secara sensus sebanyak 50 orang. Hasil penelitian menunjukkan sikap pengumpul pajak berpengaruh positif terhadap efektifitas pemungutan pajak. Motivasi pengumpul pajak positif berpengaruh terhadap efektivitas pemungutan pajak. Kemampuan pengumpul pajak tanah dan bangunan berpengaruh positif terhadap efektifitas pemungutan pajak properti. Efektivitas pengumpulan pajak atas tanah dan bangunan dengan skor tinggi pada indikator tingkat pendapatan yang masuk kategori baik. Ini berarti efektivitas pengumpulan pajak dipengaruhi oleh indikator tingkat pendapatan. Efektivitas pengumpulan pajak atas tanah dan bangunan dipengaruhi secara positif oleh sikap, motivasi, dan kemampuan untuk mengumpulkan dan mengumpulkan penagih pajak. Berarti semakin baik sikap, motivasi dan kemampuan penagih pajak tanah dan bangunan, maka efektifitas pemungutan pajak atas tanah dan bangunan akan lebih efektif
\end{abstract}

Kata Kunci: Sikap, Motivasi, Kemampuan, Efektif

\begin{abstract}
The problems of this study are as follows: How does the attitude, motivation and the ability of workers collectors on the effectiveness of tax collection on land and buildings. This study will be conducted using descriptive analysis method with survey techniques. The population in this study is the tax collector clerk in Banjar. Technique sampling use cencus as many as 50 people. The results showed Attitudes property tax collector positive influence on the effectiveness of property tax collection. Motivation property tax collector positive influence on the effectiveness of property tax collection. The ability of land and building tax collector positive influence on the effectiveness of property tax collection. The effectiveness of tax collection on land and buildings with high scores on indicators of income levels that are in either category. This means that the effectiveness of tax collection is influenced by income level indicator. The effectiveness of tax collection on land and building positively influenced by attitudes, motivation and the ability to land and building tax collector. Means the better the attitude, motivation and the ability of land and building tax collector, then the effectiveness of tax collection on land and building will be more effective.
\end{abstract}

Keywords: Attitude, Motivation, Ability, Effectiveness 


\section{PENDAHULUAN}

Sejalan dengan perkembangan ekonomi, teknologi informasi, sosial, dan politik, disadari bahwa perlu dilakukan perubahan undangundang tentang ketentuan umum dan tata cara perpajakan. Perubahan tersebut bertujuan untuk lebih memberikan keadilan, meningkatkan pelayanan kepada wajib pajak meningkatkan kepastian dan penegakan hukum, serta mengantisispasi kemajuan di bidang teknologi informasi dan perubahan ketentuan material di bidang perpajakan. Selain itu, perubahan tersebut juga dimaksudkan untuk meningkatkan profesionalisme aparatur perpajakan, meningkatkan keterbukaan administrasi perpajakan, dan meningkatkan kepatuhan sukarela wajib pajak.

Merujuk pada Undang-undang Nomor 28 Tahun 2009 tentang Pajak Daerah dan Retribusi Daerah (UU PDRD), maka Pajak Bumi dan Bangunan Pedesaan Perkotaan (PBB-P2) menjadi Pajak Kabupaten/Kota. Pengalihan pengelolaan PBB-P2 antara lain dimaksudkan untuk memperkuat Pendapatan Asli Daerah (PAD) dan untuk lebih mengoptimalkan pemungutan PBB-P2 karena Pemerintah Daerah dianggap lebih memahami kondisi Objek Pajak/Subjek Pajak di wilayahnya, serta lebih mendekatkan pelayanan kepada Wajib Pajak.

Dengan berlakunya undang-undang tersebut, maka jelas bahwa tuntutan akan pemberdayaan kemampuan daerah dalam pengelolaan sumber daya dan otonominya akan semakin mengedepan, besar dan komplek. Tuntutan terhadap peningkatan kualitas dan kuantitas pelayanan umum dan penyediaan barang kebutuhan masyarakat yang semakin beragam dan komplek, mengharuskan daerah untuk mampu mengelola pembangunan di daerah secara lebih efisien, efektif, transparan, akuntabilitas, responsive sesuai dengan pilihan, serta kebutuhan masyarakat, menuju masyarakat madani dalam konteks "Good Governance“.

Di Kota Banjar pelaksanaan pemungutan Pajak Bumi dan Bangunan pada sektor Pedesaan dan Perkotaan tersebut diserahkan pada Keluhaan/Desa sebagaimana tertuang dalam Keputusan Wailkota Banjar nomor 973/KPTS.11a-DPPKA/2014 tentang penunjukan koordinator petugas pemungut Pajak Bumi dan Bangunan pada Kecamatan dan Kelurahan/Desa Lingkup Pemerintah Kota Banjar. Pelaksanaan pemungutan yang dilakukan oleh Kelurahan/Desa dalam 
pelaksanaannya telah mengerahkan semua potensi baik sarana prasarana maupun tenaga sumber daya manusia yang dimiliki Kelurahan/Desa pada umumnya sangat terbatas, pada kurangnya sarana transportasi yang merupakan sarana utama untuk melakukan kegiatan pemungutan pada wajib pajak mengalami banyak hambatan/kendala. Hal ini dihadapkan pada kondisi wajib pajak maupun kondisi geografis yaitu letak yang berjauhan satu wajib pajak dengan yang lainnya, dan kurangnya sarana administrasi seperti kelengkapan komputer, printer dan alat tulis kantor lainnya yang sering dibutuhkan untuk memproses permohonan pembetulan, pengurangan atau keberatan yang diajukan wajib pajak, laporan mingguan tentang hasil pemungutan dan lain sebagainya.

Kondisi pegawai yang dimiliki yaitu rata-rata tiap Kelurahan/Desa sebanyak 15 (lima belas) pegawai. Kondisi pegawai dilihat dari tingkat pendidikan sebagian besar masih rendah dan pegawai tersebut rata-rata berusia diatas 40 (empat puluh) tahun dengan tingkat kemampuan yang dimiliki mereka masih rendah, terlihat saat melakukan komunikasi dengan wajib pajak penjelasannya belum dapat diterima dengan jelas oleh wajib pajak. Belum lagi administrasi yang mestinya dilakukan pada setiap lembaga yaitu mengagendakan suatu kegiatan, dengan strategi pemungutan pajak agar efektif dan efisien, merapihkan administrasi keuangannya dan lain sebagainya, belum dapat dilaksanakan dengan sempurna yang akhirnya berakibat pada kurang tertibnya penerimaan pemungutan dan tertib administrasi Pajak Bumi dan Bangunan tersebut.

Fenomena tersebut dipengaruhi oleh banyak faktor yaitu baik dari kesadaran wajib pajak maupun dari petugas pemungut. Mengingat cakupan yang sangat luas, maka dalam penelitian ini peneliti hanya melihat pada para petugas pemungut dengan segala keterbatasannya untuk melaksanakan tugas sebagai pelayanan masyarakat yaitu melakukan pemungutan Pajak Bumi dan Bangunan kepada wajib pajak. Peneliti hanya melihat pada unsur sikap, motivasi dan kemampuan petugas pemungut yang mempengaruhi efektivitas pemungut Pajak Bumi dan Bangunan. Dengan demikian, apabila dilakukan pembenahan terhadap kondisi dari petugas pemungut tersebut maka dapat mempengaruhi sikap dari wajib Pajak Bumi dan Bangunan itu sendiri, sehingga penerimaan Pajak Bumi dan 
Bangunan di Kota Banjar mencapai hasil yang optimal.

\section{KAJIAN TEORI DAN}

\section{PENGEMBANGAN HIPOTESIS}

Menurut Indrawijaya (2012) sikap atau attitude dapat didefinisikan sebagai "a predisposition to react in some manner to an individual or situation" yang secara bebas dapat diterjemahkan sebagai suatu cara bereaksi terhadap suatu rangsangan yang timbul dari seseorang atau dari suatu situasi. Hal ini dapat dijelaskan bahwa sikap seseorang merupakan perpanduan antara masa lampaunya dengan keadaan lingkungan masa kini. Disimpulkan bahwa sikap adalah suatu pandangan atau ketetapan hati terhadap suatu obyek yang akan diikuti perbuatan dengan menunjukan kepuasan dan disiplin. Dalam kepuasan yaitu suatu sikap puas yang dipunyai individu mengenai pekerjaan dengan indikator yaitu: (a) Tingkat kepuasan petugas pemungut Pajak Bumi dan Bangunan terhadap tugasnya; (b) Tingkat kepuasan petugas pemungut Pajak Bumi dan Bangunan terhadap lingkungan kerja.

Disiplin yaitu ketaatan petugas pemungut Pajak Bumi dan Bangunan terhadap segala peraturan yang berlaku, dengan indikator: (a)
Kepatuhan petugas pemungut Pajak Bumi dan Bangunan pada jam-jam kerja; (b) Kepatuhan petugas pemungut Pajak Bumi dan Bangunan terhadap peraturan yang berlaku; (c) Kepatuhan petugas pemungut Pajak Bumi dan Bangunan terhadap disiplin setor.

Hasibuan (2006) mendefinisikan motivasi sebagai pemberian daya penggerak yang menciptakan kegairahan kerja seseorang, agar mereka mau bekerja sama, bekerja efektif dan terintegrasi dengan segala daya upaya untuk mencapai kepuasan". Menurut Siagian (2002), motivasi merupakan keseluruhan proses pemberian motif kerja kepada bawahan sedemikian rupa sehingga mereka mau bekerja ikhlas demi tercapainya tujuan organisasi dengan efisien dan ekonomis.

\section{Pengertian Kemampuan}

Moekijat (2012) mendefinisikan kemampuan sebagai keahlian dan keterampilan sumber daya manusia yang penting bagi organisasi dan penting untuk masyarakat dan tidak boleh diabaikan. Kemampuan kognitif menunjukan kapabilitas berkaitan dengan akuisisi dan aplikasi pengetahuan dalam pemecahan masalah (Colquitt, LePine, dan Wesson, 2011). Dalam kemampuan intelektual yaitu kemampuan yang diperlukan untuk 
mengerjakan pemungutan Pajak Bumi dan Bangunan dengan indikatornya yaitu: (a) Kemampuan untuk dapat memberikan pemahaman kepada wajib pajak tentang Pajak Bumi dan Bangunan; (b) Kemampuan untuk dapat memberikan pelayanan kepada wajib Pajak Bumi dan Bangunan; (c) Kemampuan untuk dapat melaksanakan tugas pemungutan Pajak Bumi dan Bangunan kepada wajib pajak; (d) Kemampuan untuk dapat menyesuaikan dengan lingkungan kantor kelurahan/desa dan lingkungan obyek dan subyek pajak; (e) Kemampuan untuk dapat merencanakan program kegiatan pemungutan dan pelaporannya.

Kemampuan fisik yaitu kemampuan yang diperlukan untuk melaksanakan tugastugas yang menuntut stamina, kekuatan, ketrampilan dan kecakapan, dengan indikatornya yaitu: (a) Kemampuan yang membutuhkan stamina untruk melaksanakan tugas dalam kurun waktu tertentu; (b) Kemampuan yang membutuhkan ketrampilan untuk menggerakkan suatu alat perkantoran; (c) Kemampuan yang membutuhkan kecakapan dalam menghitung basil penerimaan Pajak Bumi dan Bangunan.

Efektivitas merupakan salah satu pencapaian yang ingin diraih oleh sebuah organisasi. Untuk memperoleh teori efektivitas, penelitian dapat menggunakan konsep-konsep dalam teori manajemen dan organisasi khususnya yang berkaitan dengan efektivitas. Efektivitas tidak dapat disamakan dengan efisiensi walaupun dalam berbagai penggunaan efisiensi lekat dengan efektivitas. Keduanya memiliki arti yang berbeda. Efisiensi mengandung pengertian perbandingan antara biaya dan hasil, sedangkan efektivitas secara langsung dihubungkan dengan pencapaian tujuan. Kata efektif berasal dari bahasa inggris yaitu effective yang berarti berhasil atau sesuatu yang dilakukan berhasil dengan baik. Kamus ilmiah populer mendefinisikan efektivitas sebagai ketepatan penggunaan, hasil guna atau menunjang tujuan. Sebagaimana dikemukakan oleh Emerson dalam Handayaningrat (2013) bahwa sesuatu dikatakan efektif adalah jika suatu tujuan atau sasaran yang telah tercapai sesuai dengan rencana. Dalam pengertian tersebut ditekankan pada pencapaian sasaran program dengan target waktu dan tujuan yang telah ditetapkan sebelumnya.

\section{Hubungan Sikap terhadap Efektivitas}

Schermerhorn, dkk, (2011) mendeskripsikan bahwa sikap adalah suatu kecenderungan merespon secara positif atau negatif pada seseorang atau sesuatu dalam lingkungannya. Sikap akan tampak 
apabila kita mengatakan suka atau tidak suka akan sesuatu atau seseorang. Sikap merupakan suatu proses yang dimulai dengan adanya interaksi kemudian membentuk suatu persepsi tentang suatu objek psikologis, sehingga komponen kognisi melukiskan objek tersebut dan sekaligus dikaitkan dengan objek-objek lain di sekitarnya. Berdasarkan pemahamannya, maka komponen afeksi memiliki penilaian emosional yang bersifat positif atau negatif. Dengan dasar penilaian tersebut maka seseorang akan bertingkah laku terhadap objek tersebut.

Perancangan tugas dan pekerjaan merupakan bagian dari proses penyusunan organisasi secara keseluruhan dalam organisasi birokrasi. Perancangan tugas pekerjaan dilakukan atas dasar prinsip rasionalitas dan reliabilitas yang tinggi, disertai standarisasi dan spesialisasi. Memang tidak dapat dipungkiri bahwa pelaksanaan prinsip-prinsip tadi memang dapat menimbulkan efisiensi. Tetapi pelaksanaannya secara ketat dapat menimbulkan terjadinya kelambatan komunikasi dan informasi, keengganan untuk berubah, atau menonjolnya bidang pekerjaan tertentu. Kemungkinan terakhir ini sering terjadi bila beberapa unit lebih mementingkan prestasi unit masing-masing dan kurang memperhatikan prestasi organisasi secara keseluruhan.
Faktor lingkungan juga mempengaruhi efektivitas organisasi, begitu pula keadaan politik, perkembangan keadaan ekonomi, sistem nilai masyarakat terhadap prestasi seseorang dan prestasi organisasi. Menarik untuk dicermati perkembangan sikap dan perilaku organisasi bila dihubungkan dengan proses pertumbuhan suatu organisasi.

\section{Hubungan Motivasi dengan Efektivitas}

Hasibuan (2012) mengemukakan motivasi sebagai pemberian daya penggerak yang menciptakan kegairahan kerja seseorang, agar mereka mau bekerjasama, bekerja efektif, dan terintegrasi dengan segala daya upayanya untuk mencapai kepuasan.

Sebagaimana dikatakan oleh McClelland (dalam Indrawijaya, 2012) bahwa motivasi merupakan akibat dari interaksi seseorang dengan situasi tertentu yang dihadapinya. Karena itulah terdapat perbedaan dalam kekuatan motivasi yang ditunjukkan oleh seseorang dalam menghadapi situasi tertentu dibandingkan dengan orang lain yang menghadapi situasi yang sama. Bahkan, seseorang akan menunjukkan dorongan tertentu dalam menghadapi situasi yang berbeda dan dalam waktu yang berlainan pula. Maka dari itu, diperlukan pemenuhan kebutuhan dan pemberian dorongan yang tepat bagi petugas pemungutan Pajak Bumi dan Bangunan (PBB) dalam rangka 
memelihara efektivitas kerja yang baik bagi pelaksanaan tugas pemungutan. Kedua jenis motivasi tersebut, motivasi intern (yang bersumber dari pemenuhan kebutuhan) dan motivasi ekstern (yang bersumber dari pemberian dorongan) dapat mempengaruhi kehidupan perilaku petugas pemungut, yang pada hakekatnya adalah berorientasi pada tujuan organisasi.

Motivasi kerja sangat dibutuhkan untuk mencapai tujuan organisasi, walaupun masingmasing individu memilki motif dan tujuan yang berbeda. Agar tercipta suatu kondisi yang lebih baik dalam sebuah organisasi, maka pemenuhan kebutuhan dan pemberian dorongan sebagai timbal balik atas pengorbanan petugas pemungut dalam pencapaian target perlu menjadi perhatian. Sebab akan membawa pengaruh terhadap penciptaan kondisi yang lebih baik dalam sebuah organisasi.

\section{Hubungan Kemampuan dengan Efektivitas}

Menurut Grenberg dan Baron (2013), kemampuan intelektual mencakup 4 aspek yaitu:

1. Cognitive intelligence merupakan kemampuan memahami gagasan yang komplek untuk menyesuaikan secara efektif terhadap lingkungan, belajar dari pengalaman, terikat dalam berbagai bentuk pertimbangan, dan mengatasi hambatan dengan pemikiran hatihati.
2. Pracetical intelligence merupakan ketangkasan dalam menyelesaikan masalah praktis secara efektif dalam kehidupan sehari-hari. Keberhasilan mereka untuk menyelesaikan masalah adalah dengan menggunakan tacit knowledge, pengetahuan tentang bagaimana segala sesuatu dapat dilakukan.

3. Emotional intelligence merupakan sekelompok keterampilan yang berhubungan dengan sisi emosional dari kehidupan.

4. Successful intelligence merupakan kecerdasan yang menunjukan keseimbangan yang baik antara Cognitive intelligence (IQ), Practical intelligence, dan creative intelligence. Creative intelligence menyangkut kemampuan berfikir fleksibel dan berada di depan kelompok..

Kemampuan atau ability berdampak pada job performance atau kinerja dan Comitmment atau komitmen namun juga bergantung pada jenis kemampuannya (cognitive, emotional atau physical). Tekanannya adalah pada general cognitive ability karena merupakan bentuk kemampuan yang paling relevan untuk semua pekerjaan. General cognitive ability merupakan prediktor paling kuat dari job performance, pada khususnya aspek task performance. Di semua pekerjaan, pekerja yang lebih cerdas memenuhi semua kebutuhan deskripsi pekerjaan lebih efektif 
daripada pekerja yang kurang cerdas.

Hal tersebut terjadi karena pekerja dengan general cognitive ability yang lebih tinggi cenderung lebih baik dalam pembelajaran dan pengambilan keputusan. Mereka dapat memanfaatkan lebih banyak pengetahuan dari pengalaman yang lebih cepat, dan sebagai hasilnya mereka mengembangkan pengetahuan yang lebih besar tentang bagaimana melakukan pekerjaan yang lebih efektif. Petugas pemungut sebaiknya mempunyai kemampuan kognitif lebih tinggi cenderung bekerja lebih efektif, dan karena itu mungkin mereka merasa sangat sesuai dengan pekerjaan mereka.

\section{Hubungan Sikap, Motivasi dan Kemampuan dengan Efektivitas}

Keefektifan organisasi tidak dipandang sebagai suatu variabel yang berdiri sendiri tetapi disebabkan pula oleh variabel lainnya yaitu sebab-sebab keefektifan, Steers (2013) mengidentifikasikan sebab-sebab keefektifan organisasi kelompok dan individu.

Pendapat Streers tersebut di atas dapat dijelaskan bahwa pada efektivitas individu sebab-sebabnya terdiri dari kemampuan, ketrampilan, pengetahuan, sikap, motivasi dan stres. Efektivitas kelompok sebab-sebabnya tendiri dari kepanduan, kepemimpinan, struktur, status, peran, dan norma-norma. Sedang efektivitas organisasi sebab-sebabnya terdiri dari lingkungan, teknologi, pilihan strategi, struktur, proses, dan kultur ini semua mempunyai hubungan sebab dari variabel oleh variabel lainnya.

Dijelaskan bahwa efektifitas setiap organisasi sangat dipengaruhi oleh perilaku manusia. Manusia merupakan sumberdaya yang umum bagi semua organisasi. Kinerja organisasi tergantung dari kinerja individu. Manajer harus mempunyai lebih dari sekedar pengetahuan dalam hal penentuan kinerja individu. Psikologi sosial memberikan konstribusi atas pengetahuan yang relevan mengenai hubungan antara sikap, persepsi, kepribadian, nilai-nilai dan kinerja individu. Dalam kemampuan sifat biologis dan yang bisa dipelajari yang memungkinkan seseorang melakukan sesuatu baik bersifat mental maupun fisik. Ketrampilan kompentensi berhubungan dengan pekerjaan. Sikap adalah determinan perilaku sebab, sikap berkaitan dengan persepsi, kepribadian dan motivasi. Sebuah sikap adalah perasaan positif atau negatif atau keadaan mental yang selalu disiapkan, dipelajari, dan diatur melalui pengalaman, yang memberikan pengaruh khusus pada respon seseorang terhadap orang, 
objek-objek dan keadaan. Motivasi adalah kekuatan yang mendorong seseorang pegawai menimbulkan dan mengarahkan perilaku. stres merupakan akibat utama atas interaksi antara pekerjaan dan individu.

Steers (2013) mengemukakan bahwa hal yang penting dalam proses pencapaian efektivitas adalah penggunaan sistem perspektif yang terbuka untuk melakukan analisa. Pendekatan tersebut menekankan hubungan antar bagian organisasi dengan lingkungannya. Dengan menggunakan perspektif ini, kita dapat mengidentifikasikan empat kategori utama yang mempengaruhi efektivitas yaitu: (a) Sifat organisasi seperti struktur dan teknologi; (b) Sifat lingkungan seperti kondisi ekonomi dan pasar; (c) Sifat pegawai seperti tingkat kinerja dan prestasi pegawai; (d) Kebijakan dan praktek manajerial.

Keempat variabel di atas, saling berhubungan satu sama lainnya dalam upaya pencapaian efektivitas organisasi.

Terdapat 4 (empat) faktor pokok yang mempengaruhi efektivitas organisasi (Steers, 2013) yaitu: (1) Karakteristik organisasi adalah struktur menyatakan cara organisasi mengatur sumber daya manusia bagi kegiatan-kegiatan ke arah tujuan; (2) Karakteristik lingkungan mencakup lingkungan ekstern dan intern; (3) Karakteristik pekerja atau pegawai adalah unsur terpenting dalam suatu organsasi. Ini membawa konsekuensi kepada para pimpinan untuk lebih dapat mengetahui keadaan pegawainya, sebagai pegawai yang berlainan latar belakang dan sebagai manusia mempunyai pandangan, tinjauan, kebutuhan, karakter dan kemampuan yang relatif berbeda dengan yang lainnya walaupun ditempatkan dalam suatu lingkungan kerja yang sama; (4) Kebijakan dan praktek manajemen seorang manajer atau pimpinan unit maupun pimpinan puncak dalam organisasi mempunyai tanggung jawab yang besar terhadap keberhasilan organisasi dalam mencapai tujuannya. Berdasarkan uraian di atas, kerangka pemikiran penelitian ini dapat digambarkan sebagaimana tertera dalam gambar 1.

Dalam penelitian ini dikembangkan hipotesis sebagai berikut:

1. Sikap berpengaruh positif terhadap efektivitas pemungutan pajak

2. Motivasi berpengaruh positif terhadap efektivitas pemungutan pajak

3. Kemampuan berpengaruh positif terhadap efektivitas pemungutan pajak

4. Sikap, motivasi dan kemampuan berpengaruh positif terhadap efektivitas pemungutan pajak. 


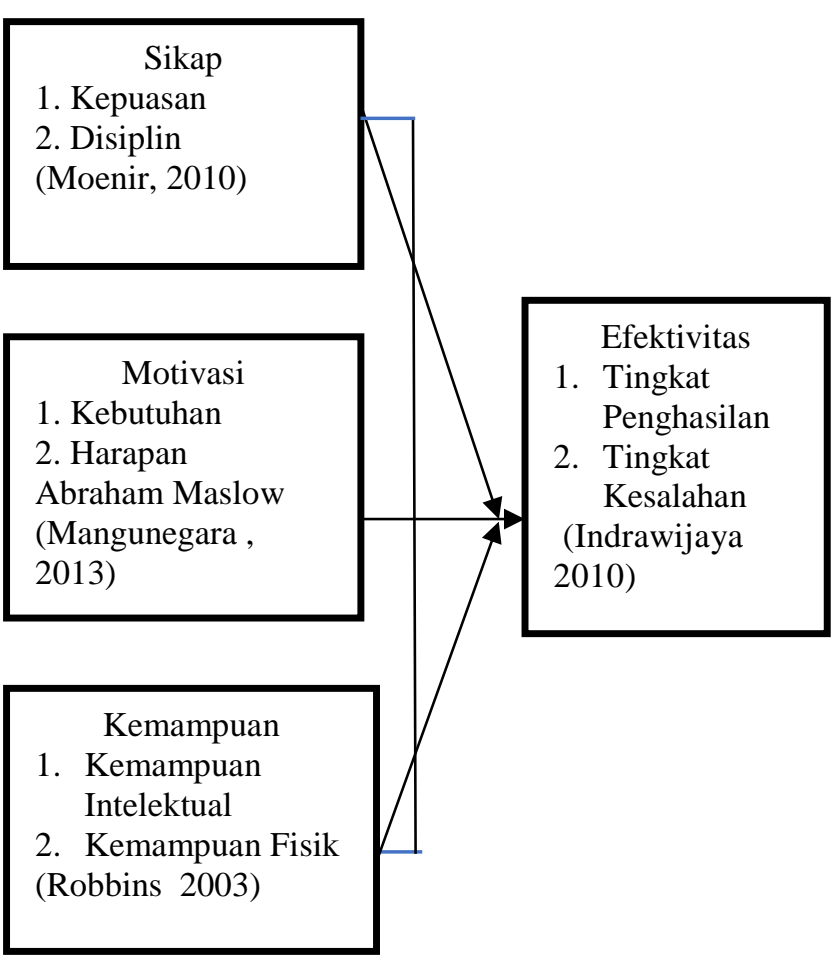

Gambar 1. Kerangka Pemikiran

\section{METODE RISET}

Penelitian ini menggunakan metode deskriptif kausal-komparatif, di mana penelitian ini bertujuan untuk menyelidiki kemungkinan hubungan sebab akibat antara faktor tertentu yang mungkin menjadi penyebab gejala yang diselidiki. Populasi penelitian ini adalah Kepala Kelurahan/Desa dan Kolektor Pemungut di Kota Banjar sebanyak 50 orang sehingga semuanya dijadikan sampel penelitian. Pengujian hasil penelitian dilakukan menggunakan analisis multivariat yaitu analisis korelasi dan regresi, karena menyangkut hubungan antara dua variabel atau lebih. Analisis korelasi digunakan untuk mengetahui apakah di antara kedua variabel terdapat hubungan atau tidak. Jika ternyata berhubungan, bagaimana arah ada hubungan tersebut, dan seberapa besar hubungan tersebut. Analisis regresi digunakan untuk mengetahui hubungan antara variabel independen dan variabel dependen. Adapun analisis regresi yang digunakan adalah analisis regresi berganda (multiple regression) karena dalam penelitian ini menggunakan tiga variabel independen dan satu variabel dependen.

\section{HASIL PENELITIAN DAN}

\section{PEMBAHASAN}

\section{Pengaruh Sikap terhadap Efektifitas}

Dari hasil perhitungan yang dilakukan (tabel 1), diperoleh nilai korelasi product moment sebesar 0,675 termasuk pada kategori kuat. Jadi terdapat pengaruh yang kuat dari sikap pemungut Pajak Bumi dan Bangunan terhadap efektifitas pemungutan Pajak Bumi dan Bangunan di Kota Banjar. Selanjutnya untuk mengetahui pengaruh sikap pemungut Pajak Bumi dan Bangunan terhadap efektifitas pemungutan Pajak Bumi dan Bangunan di Kota Banjar, dapat dihitung besarnya koefesien determinan sebesar $45 \%$. Dengan demikian dapat disimpulkan berdasarkan hasil 
perhitungan, pengaruh dari sikap pemungut Pajak Bumi dan Bangunan terhadap efektifitas pemungutan Pajak Bumi dan Bangunan di Kota Banjar sebesar 45,5\%. Untuk menjawab hipotesis yang peneliti ajukan, maka peneliti menggunakan angka signifikansi dengan tinggi keyakinan $95 \%$ atau $\alpha=0,05$ dan diperoleh angka signifikansi sebesar $0,021<0,05$. Hasil ini menunjukkan bahwa hipotesis Ho ditolak atau dengan kata lain bahwa "Ada pengaruh yang kuat dari sikap pemungut Pajak Bumi dan Bangunan terhadap efektifitas pemungutan Pajak Bumi dan Bangunan di Kota Banjar".

Hal ini sejalan dengan pendapat Schermerhorn, dkk, (2011) bahwa sikap kerja dapat dijadikan indikator apakah suatu pekerjaan berjalan lancar atau tidak. Jika sikap kerja dilaksanakan dengan baik, pekerjaan akan berjalan lancar. Jika tidak, berarti akan mengalami kesulitan. Karyawan atau pegawai yang memiliki sikap kerja baik dapat bekerja dan akan melakukan pekerjaannya dengan baik. Hal ini tentu berbeda jika karyawan atau pegawai yang memiliki sikap kerja kurang baik, tentu akan bekerja dengan asal-asalan sehingga akan berdampak pada tidak efektifnya hasil kerja.
Tabel 1. Hubungan X1, X2, dan X3 dengan $Y$

\begin{tabular}{|l|c|l|l|l|}
\hline \multicolumn{1}{|c|}{ Variabel } & $\mathrm{R}$ & $\begin{array}{c}\mathrm{R} \\
\text { Square }\end{array}$ & Beta & Sig \\
\hline $\mathrm{X}_{1} \mathrm{Y}$ & 0,675 & 0,455 & 0,232 & 0,021 \\
\hline $\mathrm{X}_{2} \mathrm{Y}$ & 0,769 & 0,591 & 0,451 & 0,000 \\
\hline $\mathrm{X}_{3} \mathrm{Y}$ & 0,723 & 0,523 & 0,333 & 0,001 \\
\hline & & & 0,232 & \\
$\mathrm{X}_{1, \mathrm{X}_{2}, \mathrm{X}_{3} \mathrm{Y}}$ & 0,863 & 0,745 & 0,451 & 0,000 \\
& & & 0,333 & \\
\hline
\end{tabular}

Sumber: Hasil Analisis Data

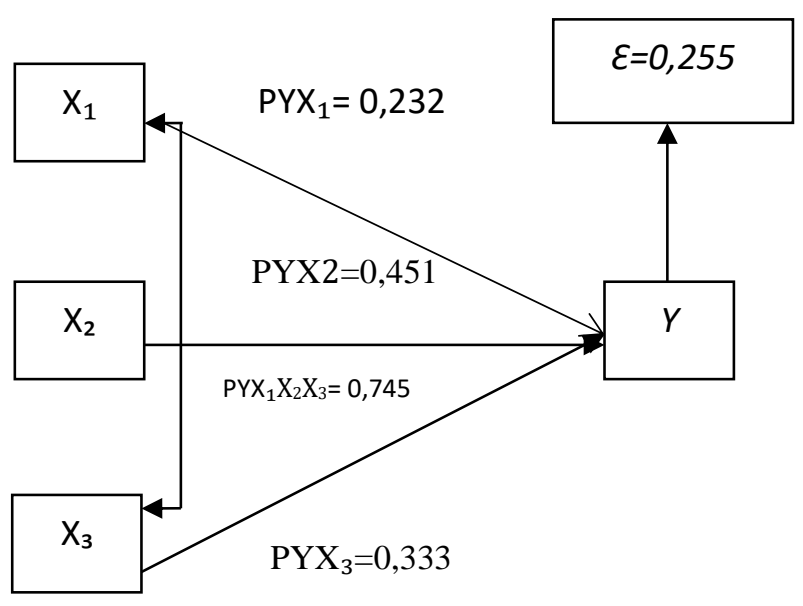

Gambar 2. Hubungan Antar Variabel

\section{Pengaruh Motivasi terhadap Efektifitas}

Dari perhitungan di atas diperoleh nilai korelasi product moment sebesar 0,769 yang termasuk ketegori kuat. Jadi terdapat pengaruh yang kuat dari motivasi pemungut Pajak Bumi dan Bangunan terhadap efektifitas pemungutan Pajak Bumi dan Bangunan di Kota Banjar. Selanjutnya untuk mengetahui pengaruh motivasi pemungut Pajak Bumi dan Bangunan terhadap efektifitas pemungutan Pajak Bumi dan Bangunan di Kota Banjar, dapat dihitung besarnya koefesien determinan sebesar 59,1\%, maka pengaruh dari motivasi pemungut Pajak 
Bumi dan Bangunan terhadap efektifitas pemungutan Pajak Bumi dan Bangunan di Kota Banjar sebesar 59,1\%. Untuk menjawab hipotesis yang peneliti ajukan, maka peneliti menggunakan sig dengan tinggi keyakinan 95\% atau $\alpha=0,05$ dan diperoleh angka signifikansi sebesar $0,000<0,05$ Maka hipotesis Ho ditolak atau dengan kata lain, Ada pengaruh yang kuat dari motivasi pemungut Pajak Bumi dan Bangunan terhadap efektifitas pemungutan Pajak Bumi dan Bangunan di Kota Banjar.

Hasil ini sependapat dengan Hasibuan (2012) bahwa motivasi dapat menciptakan kegairahan kerja seseorang, sehingga mereka mau bekerjasama, dan bekerja efektif. Pentingnya motivasi adalah karena motivasi merupakan semangat dan dorongan untuk melaksanakan pekerjaan dengan sebaikbaiknya.

\section{Pengaruh Kemampuan terhadap Efektifitas}

Dari perhitungan di atas diperoleh nilai korelasi product moment sebesar 0,723 berada pada interval interval 0,60-0,799 yang termasuk ketegori kuat. Jadi terdapat pengaruh yang kuat dari kemampuan pemungut Pajak Bumi dan Bangunan terhadap efektifitas pemungutan Pajak Bumi dan Bangunan di Kota Banjar.
Selanjutnya untuk mengetahui pengaruh kemampuan pemungut Pajak Bumi dan Bangunan terhadap efektifitas pemungutan Pajak Bumi dan Bangunan di Kota Banjar, dapat dihitung besarnya koefesien determinan sebesar 52,3\%. Dengan demikian dapat disimpulkan berdasarkan hasil perhitungan bahwa pengaruh dari kemampuan pemungut Pajak Bumi dan Bangunan terhadap efektifitas pemungutan Pajak Bumi dan Bangunan di Kota Banjar sebesar 52,3\%. Untuk menjawab hipotesis yang peneliti ajukan, maka peneliti menggunakan sig dengan tinggi keyakinan 95\% atau $\alpha=0,05$ dan diperoleh angka signifikansi sebesar $0,001<0,05$ Maka hipotesis Ho ditolak Ho ditolak dengan kata lain bahwa ada pengaruh yang kuat dari kemampuan pemungut Pajak Bumi dan Bangunan terhadap efektifitas pemungutan Pajak Bumi dan Bangunan di Kota Banjar.

Kemampuan kerja merupakan suatu keadaan yang ada pada diri pekerja yang secara sungguh-sungguh berdaya guna dan berhasil guna dalam bekerja sesuai bidang pekerjaannya. Pada dasarnya manusia memiliki kekuatan dan kelemahan dalam hal kemampuan yang membuatnya relatif unggul atau sebaliknya dibandingkan orang lain dalam 
melakukan tugas atau kegiatan tertentu.

Pegawai yang memiliki kemampuan baik tentu dapat menyelesaikan pekerjaannya dengan baik dibandingkan dengan pegawai yang memiliki kemampuan kurang.

Pengaruh Sikap, Motivasi dan Kemampuan terhadap Efektifitas

Dari perhitungan di atas, diperoleh nilai korelasi product moment sebesar 0,863 berada pada interval interval $0,80-1$ yang termasuk ketegori sangat kuat. Jadi terdapat pengaruh yang sangat kuat dari sikap, motivasi dan kemampuan pemungut Pajak Bumi dan Bangunan terhadap efektifitas pemungutan Pajak Bumi dan Bangunan di Kota Banjar. Selanjutnya untuk mengetahui pengaruh sikap, motivasi dan kemampuan pemungut Pajak Bumi dan Bangunan terhadap efektifitas pemungutan Pajak Bumi dan Bangunan di Kota Banjar, dapat dihitung besarnya koefesien determinan sebesar $74,5 \%$.

Dengan demikian dapat disimpulkan berdasarkan hasil perhitungan bahwa pengaruh dari sikap, motivasi dan kemampuan pemungut Pajak Bumi dan Bangunan terhadap efektifitas pemungutan Pajak Bumi dan Bangunan di Kota Banjar sebesar 74,5\%. Untuk menjawab hipotesis yang peneliti ajukan, maka peneliti menggunakan sig. dengan tinggi keyakinan $95 \%$ atau $\alpha=0,05$ dan diperoleh angka signifikansi sebesar $0,000<0,05$ Maka hipotesis Ho ditolak Ho ditolak dengan kata lain bahwa Ada pengaruh yang kuat dari sikap, motivasi dan kemampuan pemungut Pajak Bumi dan Bangunan terhadap efektifitas pemungutan Pajak Bumi dan Bangunan di Kota Banjar.

Sikap berpengaruh signifikan terhadap efektivitas kerja pegawai, karena pegawai yang memiliki sikap baik, mau menerima arahan pemimpin, kejujuran dalam bekerja, dan tanggung jawab terhadap pekerjaan maka tercapailah efektivitas kerja pegawai. Kemampuan (abilities) menunjukkan potensi seseorang untuk melaksanakan tugas atau pekerjaan. kemampuan seseorang merupakan perwujudan dari pengetahuan dan keterampilan yang dimiliki. Kemampuan sebagai potensi yang dimiliki oleh seseorang untuk melakukan pekerjaan maupun tugas-tugas sehingga hasil yang dicapai sesuai dengan yang diharapkan. Pegawai yang memiliki kemampuan kerja yang baik dapat menyelesaikan pekerjaannya sesuai waktu yang ditetapkan dalam program kerja.

Motivasi mempunyai hubungan yang sangat erat dengan efektivitas kerja, Efektifitas 
kerja hanya dapat dicapai jika pegawai memiliki semangat dalam bekerja. Motivasi kerja tidak mungkin dimiliki pegawai apabila tidak disertai dengan perubahan, pengetahuan dan sikap karena ketiga unsur tersebut merupakan suatu masalah yang sangat penting dalam meningkatkan kerja yang sangat baik. Peningkatan pengetahuan pegawai dalam penguasaan teori dan keterampilan dimaksudkan untuk memutuskan persoalanpersoalan yang menyangkut kegiatan dalam rangka mencapai tujuan untuk menyelesaikan pekerjaan yang dilimpahkan kepadanya. Hal ini tentunya membuat kemampuan mereka di dalam bekerja menjadi meningkat sehingga membuat pegawai dapat bekerja lebih efektif.

\section{KESIMPULAN DAN SARAN}

\section{Kesimpulan}

Berdasarkan hasil penelitian dan pembahasan tentang pengaruh sikap, motivasi dan kemampuan para petugas pemungut terhadap efektivitas pemungutan Pajak Bumi dan Bangunan pada sektor perdesaan dan perkotaan, dapat penulis simpulkan sebagai berikut:

1. Sikap responden tentang pemungutan Pajak Bumi dan Bangunan dengan nilai tertinggi pada indikator disiplin berada pada kategori baik. Artinya untuk sikap responden dipengaruhi oleh indikator disiplin. Sikap pemungut Pajak Bumi dan Bangunan berpengaruh terhadap efektifitas pemungutan Pajak Bumi dan Bangunan di Kota Banjar. Artinya semakin baik sikap pemungut Pajak Bumi dan Bangunan maka efektifitas pemungutan Pajak Bumi dan Bangunan akan semakin meningkat.

2. Motivasi responden tentang pemungutan Pajak Bumi dan Bangunan dengan nilai tertinggi pada indikator harapan berada pada kategori baik. Artinya untuk motivasi responden dipengaruhi oleh indikator harapan. Motivasi pemungut Pajak Bumi dan Bangunan berpengaruh terhadap efektifitas pemungutan Pajak Bumi dan Bangunan di Kota Banjar. Artinya semakin baik motivasi pemungut Pajak Bumi dan Bangunan maka efektifitas pemungutan Pajak Bumi dan Bangunan akan semakin meningkat.

3. Kemampuan responden tentang pemungutan Pajak Bumi dan Bangunan dengan nilai tertinggi pada indikator kemampuan intelektual berada pada kategori baik. Artinya kemampuan 
responden dipengaruhi oleh indikator

kemampuan intelektual. Kemampuan

pemungut Pajak Bumi dan Bangunan

berpengaruh terhadap efektifitas

pemungutan Pajak Bumi dan Bangunan di

Kota Banjar. Artinya semakin baik

kemampuan pemungut Pajak Bumi dan

Bangunan maka efektifitas pemungutan

Pajak Bumi dan Bangunan akan semakin meningkat.

4. Efektifitas pemungutan Pajak Bumi dan Bangunan dengan nilai tertinggi pada indikator tingkat penghasilan berada pada kategori baik. Artinya efektifitas pemungutan pajak dipengaruhi oleh indikator tingkat penghasilan. Efektifitas pemungutan Pajak Bumi dan Bangunan dipengaruhi oleh sikap, motivasi dan kemampuan pemungut Pajak Bumi dan Bangunan. Artinya semakin baik sikap, motivasi dan kemampuan pemungut Pajak Bumi dan Bangunan maka efektifitas pemungutan Pajak Bumi dan Bangunan akan semakin efektif.

\section{Saran}

Berdasarkan dari hasil analisis dan pembahasan, maka saran yang dapat diberikan adalah:
1. Sikap responden tentang pemungutan Pajak Bumi dan Bangunan berada pada kategori cukup dengan skor terendah adalah penarikan pajak dari masyarakat cukup melelahkan. Hal ini perlu dilakukan penambahan insentif bagi pemungut Pajak Bumi dan Bangunan dan pemberian fasilitas yang memadai.

2. Motivasi pemungut Pajak Bumi dan Bangunan berada pada kategori baik namun perlu peningkatan terutama tentang jaminan keamanan dalam bekerja. Hal ini dapat dilakukan dengan mengikutkan pemungut Pajak Bumi dan Bangunan dalam program asuransi

3. Kemampuan pemungut Pajak Bumi dan Bangunan berada pada kategori baik namun perlu perbaikan dalam mencapai daerahdaerah yang jauh dengan cara penambahan skill petugas.

4. Efektifitas pemungutan Pajak Bumi dan Bangunan berada pada kategori baik namun perlu ada penyuluhan yang terus menerus tentang kewajiban membayar Pajak Bumi dan Bangunan. 


\section{DAFTAR PUSTAKA}

Gibson, L James, Ivancevich M John, Jr Donnelly H James, (2012) Organisasi Perilaku, Struktur, Proses, Binarupa Aksara, Jakarta.

Handayaningrat, Soewarno. (2013). Studi Ilmu Administrasi dan Manajemen. Ghalia Indonesia, Jakarta:

Hasibuan, SP Malayu H, (2012), Organisasi dan Motivasi Dasar Peningkatan Produktivitas, Cetakan Kedua, Bumi Aksara, Jakarta.

Indrawijaya, I Adam, (2010), Teori Perilaku dan Budaya Organisasi, Cetakan Pertama PT. Refika Aditama, Bandung.

Malayu S. P Hasibuan, 2012, Manajemen Sumber Daya Manusia. Edisi revisi Bumi Aksara, Jakarta

Mangkunegara, Anwar Prabu. (2013). Manajemen Sumber Daya Manusia Perusahaan. PT. Remaja Rosda Karya. Bandung

Moenir, HAS, (2010), Manajemen Pelayanan Umum di Indonesia, Cetakan Kesembilan, Bumi Aksara, Jakarta.

Siagian, P Sondang, (2013), Teori Motivasi dan Aplikasinya, Cetakan Kedua, Reneka Cipta, Jakarta.

Organisasi Kepemimpinan dan Perilaku Administrasi. Jakarta: PT. Gramedia.

Simamora, Henry, (2012) Manajemen Sumberdaya Manusia, Cetakan kedua STIE YKPN, Yogyakarta

Steers, M. Richard, (2013), Effektifltas Organisasi, Erlangga Jakarta

Sugiyono, (2013), Metode Penelitian Administrasi, Cetakan Kedua puluh satu, Alfa Beta, Bandung.

Suryaminata, Errnaya, (2013), Psikologi Kepegawaian dan Feranan Pimpinan dalam Motivasinya, Ramadan Bandung.

Waluyo, (2007), Manajemen Publik "Konsep, Aplikasi, dan Implementasinya Dalam Pelaksanaan Otonomi Daerah”.Cetakan Pertama, Mandar Maju, Bandung.

Wibowo, (2013), Perilaku Dalam Organisasi, Cetakan Pertama, PT. Rajagrafindo Persada, Jakarta. 